\title{
Reconsidering the Significance, Authenticity and Integrity of New Gourna Village within the Context of the World Heritage Convention
}

\author{
Ayman Abdel Tawab \\ Department of Architectural Engineering, Faculty of Engineering, Tanta University, Tanta, Egypt \\ Email address: \\ a_g_a_abdeltawab@yahoo.co.uk \\ To cite this article: \\ Ayman Abdel Tawab. Reconsidering the Significance, Authenticity and Integrity of New Gourna Village within the Context of the World \\ Heritage Convention. Urban and Regional Planning. Vol. 3, No. 3, 2018, pp. 92-101. doi: 10.11648/j.urp.20180303.12
}

Received: July 30, 2018; Accepted: August 20, 2018; Published: November 1, 2018

\begin{abstract}
Despite its location inside the World Heritage Site in Luxor, New Gourna Village has never been recognized as one of the elements that contribute to the World Heritage Site's Outstanding Universal Value. In order to consider New Gourna among the World Heritage Site's contributing elements, it should enjoy an Outstanding Universal Value and should also satisfy the conditions of authenticity and integrity. The aim of this study was to scrutinize the possibility to recognize New Gourna as one of the elements that contribute to the Outstanding Universal Value of the World Heritage Site in Luxor. The previous aim was achieved by evaluating the level of significance of the heritage values that New Gourna enjoys, as well as their authenticity and integrity, using a proposed methodology. According to this methodology, the level of significance of the values that New Gourna enjoys was evaluated against a list of criteria that were largely derived from the world heritage criteria. Another methodology, which was based on the Operational Guidelines' definitions of authenticity and integrity, was used to evaluate the authenticity and integrity of the village. The findings revealed the significant contribution of New Gourna towards the World Heritage Site's Outstanding Universal Value despite the decline of the village's authenticity and integrity. The continuous demolition of the buildings designed by Hassan Fathy in the village and the replacement of these buildings by modern concrete buildings represent the major aspect that emphasizes the decline of the authenticity of New Gourna. On the other hand, the decline of the physical condition of the few remaining earthen buildings designed by Hassan Fathy in the village is the main aspect that emphasizes the decline of the village's integrity. The study suggests revising the Statement of Outstanding Universal Value of the World Heritage Site in Luxor so as to recognize New Gourna among its contributing elements and to undertake all the possible measures to preserve New Gourna.
\end{abstract}

Keywords: Earthen Heritage, New Gourna Village, Hassan Fathy, World Heritage Sites, Authenticity and Integrity Evaluation

\section{Introduction}

The interest in the conservation of the patterns of cultural heritage that have been neglected for a long time has been provoked by the World Heritage Centre's Global Strategy, adopted in 1994. The study, based on which the Global Strategy has been developed, has revealed that some patterns of cultural heritage resources, as well as the heritage of some of the UNESCO's regions, are under-represented on the World Heritage List. Among the under-represented patterns of cultural heritage are vernacular heritage and recent heritage and among the under-represented UNESCO's regions are Africa and the Arab States regions [1]. Egypt belongs to the latter region. New Gourna Village in Luxor in Egypt, which has been designed by Hassan Fathy, represents the previous two under-represented patterns.

Few properties representing recent heritage have been inscribed on the World Heritage List. The Bauhaus and its Sites in Weimar and Dessau in Germany, inscribed in 1996 [2], is an example of such properties. Some African countries have listed on their Tentative Lists, of the properties that might be nominated for listing as World Heritage Sites in the future, some properties representing these under-represented heritage patterns. "La grande mosquée de vendredi de Niono" in Mali, which has been built using earth [3], and has 
been listed on Mali's Tentative List in 2008 [4], is an example of these properties.

None of the properties designed by Hassan Fathy has been inscribed on the World Heritage List, nor have any of these properties been listed on the Egyptian Tentative List [5]. Only one Egyptian World Heritage Site incorporates within its boundaries properties designed by Hassan Fathy and represent earthen heritage, which is "Ancient Thebes with its Necropolis", in Luxor (Figure 1). The site incorporates two properties designed by Hassan Fathy, which are New Gourna Village and Stopplaere House. New Gourna Village, which is the focus of this study, has never been recognized as one of the elements that contribute to the Outstanding Universal Value of the World Heritage Site, which has been inscribed merely for its archaeological value [6]. In order to recognize New Gourna as a contributing element, the village should enjoy an Outstanding Universal Value and should also satisfy the conditions of authenticity and integrity [7].

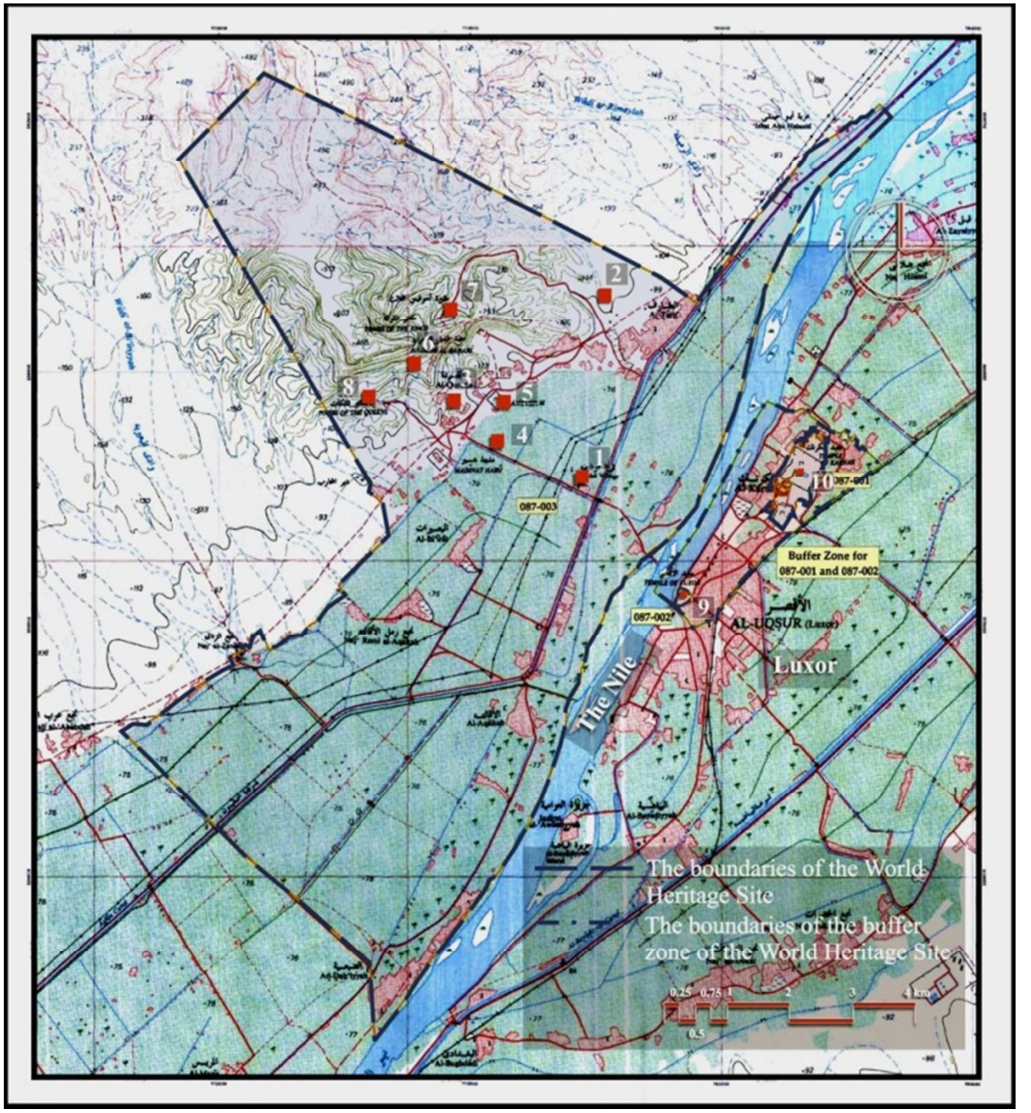

Source: Developed by the author based on the map of the Supreme Council of Antiquities in Egypt [8, p1].

Figure 1. A map that shows the boundaries of "Ancient Thebes with its Necropolis" World Heritage Site in Luxor and the location of the major architectural and archaeological sites in the property. 1. New Gourna Village, 2. Stopplaere House, 3. Old Gourna Village, 4. the Colossi of Memnon, 5. the Ramesseum, 6. Deir al-Medina, 7. Deir al-Bahari, 8. Valley of the Queens, 9. Temple of Luxor, 10. The Temple of Karnak.

\section{The Aim and the Method}

The main aim of this study was to scrutinize the possibility to recognize New Gourna Village as one of the elements that contribute to the Outstanding Universal Value of the World Heritage Site in Luxor; and to evaluate the level of significance, authenticity and integrity of the village. To evaluate the level of significance of the heritage values that New Gourna enjoys, a model of heritage values that was based on Feilden's model [9] was adopted. The adopted model classifies the various heritage values into three groups; which are the emotional values, the cultural values, and the use values; and incorporates sustainability as a subsidiary quality to the architectural value. The emotional values involve the wonder value, the identity value, the spiritual/religious value, and the respect and veneration values. The cultural values involve the historic value, the age value, the archaeological value, the newness value, the aesthetic value, the artistic value, the architectural value, the townscape and urban values, the landscape and ecological values, and the scientific value. Finally, the use values involve the functional value, the economic value, the social value, the educational value, and the political value.

To examine whether New Gourna enjoys any of the previous heritage values or not, a group of indicators were assigned to each value. For instance, two indicators were assigned to the spiritual/religious value. These two indicators are the ability of the concerned property to provoke the religious emotions associated with the beliefs and teachings of organized religions [10]; and whether the concerned property maintains physical elements that embody its spiritual/religious values, such as religious buildings [9]. In relation to the architectural value, five indicators were 
assigned to this value. The five indicators of the architectural value are the efficiency of the concerned property's function; the delight aspects of the concerned property's architectural qualities, such as its harmonious relationship with the site and its massing and silhouette; the firmness aspects of the concerned property's architectural qualities, which involve the durability of the concerned property's structure system and building materials; and the commodity aspects of the concerned property's architectural qualities, which involve the ability of the property's design to meet a wide range of different uses [9]. The fifth indicator of the architectural value is concerned with the property's efficient use of energy and resources [11] and its exceptional sustainability qualities. Finally, the economic value was assigned one indicator, which is the ability of the concerned property to encourage tourism and to make significant contributions to the local community's economic development [11].

The first step of the study was to identify the heritage values that New Gourna enjoys and to evaluate the level of significance of these values. Three criteria were adopted to evaluate the level of significance of each value; which are the interchange of the values, either over a span of time or within a geographical region [7], the values' true representation of the genuine Egyptian culture [12], and the level at which the values are experienced and appreciated [10]. Following the identification of the values that New Gourna enjoys, the elements that contribute to these values, as well as each element's relevant attributes, were identified. To evaluate the authenticity of each value that New Gourna enjoys, a methodology based on the Operational Guidelines' definition of authenticity [7] was adopted. According to this methodology, properties are considered to satisfy the conditions of authenticity if their values are truthfully and credibly expressed by the relevant attributes. The adopted attributes of authenticity involve form and design; materials and substance; use and function; traditions, techniques and management systems; location and setting; language, and other forms of intangible heritage; and spirit and feeling [13]. Another methodology was adopted to evaluate the integrity of the values that New Gourna enjoys, which was also based on the Operational Guidelines' definition of integrity [7]. According to this methodology, the evaluation of integrity focused on two aspects, which are the completeness and the condition of the relevant attributes.

\section{Introduction to the Architect and New Gourna Village}

Hassan Fathy was born in Alexandria in 1900. He graduated from Cairo University in 1926. Hassan Fathy designed more than 100 projects, many of which have been built. New Gourna Village is considered among the most significant projects that he designed [14]. In addition to New Gourna Village, Hassan Fathy designed other significant community projects, such as New Baris Village, partially constructed in 1967 in Kharga Oasis, and Garagus Cultural Centre and Ceramics Factory, constructed in 1950. Hassan Fathy also designed a number of private houses, such as Fouad Riad House, built in 1967 in Shabramant, and
Casaroni House, built in 1980 in Shabramant [14]. The works of Hassan Fathy, particularly New Gourna Village, have been appreciated on the international level [15]. Hassan Fathy passed away in 1989 [16].

New Gourna Village lies on the western bank of the Nile in Luxor close to the Colossi of Memnon. The main aim of building New Gourna Village was to relocate the local community residing inside another nearby village called Old Gourna Village. Old Gourna Village lies along the edge of one of the mountains outside Luxor very close to some of the major archaeological sites outside the city; particularly the Ramesseum, Deir al-Medina, Valley of the Queens and Deir al-Bahari archaeological sites. The government intended to relocate Old Gourna Village to its new location because the presence of the village in its original location was considered a serious threat to the nearby ancient Egyptian sites. One of the clans that inhabited Old Gourna Village, which is the Horrabat clan, was feared to be involved with tomb rubbing and illicit trafficking of ancient Egyptian artefacts, which were found in the nearby ancient Egyptian sites [17]. Hassan Fathy, who was commissioned to design the new village, chose the location of New Gourna inside the agricultural lands near the Nile River. The location of New Gourna was considered by the then standards far from the ancient Egyptian sites that were feared to be the subject of tomb rubbing. The construction of New Gourna began around 1945, and was discontinued in 1947 [18]. The built section of New Gourna involves, among the key built elements; the mosque (Figure 2), the khan (Figure 3), the theatre, Hassan Fathy's house, and a small section of the marketplace.

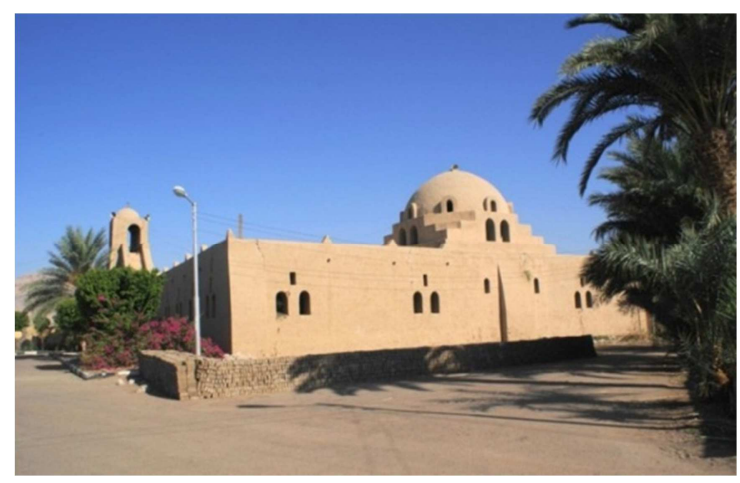

Source: Photograph by the author, September 2011.

Figure 2. The mosque in New Gourna Village.

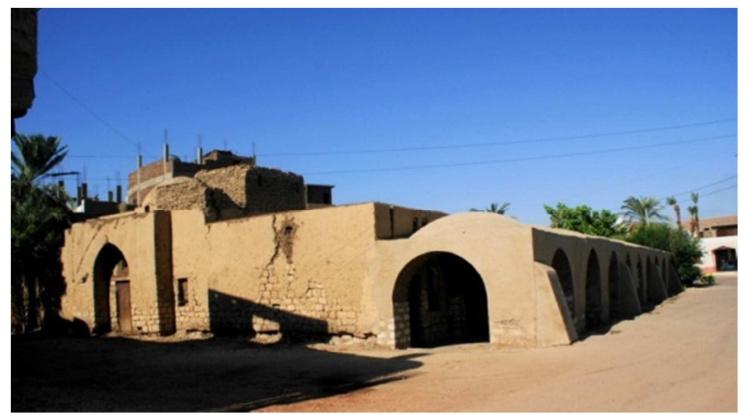

Source: Photograph by the author, September 2011.

Figure 3. The khan in New Gourna Village. 
The physical condition of New Gourna has declined dramatically in the last few years. Many of the buildings designed by Hassan Fathy have either collapsed or have been demolished and replaced by unsympathetic new buildings that suffer from their poor visual and architectural qualities. The overwhelming spread of these poorly designed new developments throughout the fabrics of the village has detracted from the village's genuine spirit and feeling. In order to stop the further decline of the condition of New Gourna, as well as the rest of Hassan Fathy's architectural heritage, an international association concerned with the preservation of the works of Hassan Fathy has been established in Switzerland since 2008 [19]. The association has contacted the World Heritage Centre and the World Monuments Fund in order to safeguard New Gourna Village. Both the World Heritage Centre and the World Monuments Fund have responded positively [19]. The World Heritage Centre has embarked upon a conservation project of the village that has been prefaced by a preliminary architectural study on the village [6]. On the other hand the World Monuments Fund has carried out another social study on the local community residing in the village [20]. The World Monuments Fund has listed New Gourna Village on its Watch List of 2010, and has also agreed to finance the conservation works in the village [21]. However, the conservation project in the village seems to have been discontinued following the revolution in 2011. In addition to the World Heritage Centre's conservation project, there have been two other individual conservation initiatives to two of the houses designed by Hassan Fathy in the village. One of these two conservation initiatives has been carried out by Fikri Hassan, who has been involved with the World Heritage Centre's conservation project. Despite the national and international interest in the conservation of New Gourna Village, the demolition of the buildings designed by Hassan Fathy in the village and the replacement of these buildings by modern concrete buildings seem to continue.

\section{The Findings of the Analysis}

\subsection{The General Findings}

The findings (Table 1) indicate that New Gourna Village is more likely to satisfy 15 heritage values. The level of significance of 14 of these 15 values is more likely to reach the international level. The evaluation of the authenticity and integrity (Table 1) of the values that New Gourna Village enjoys indicates that only five out of the 14 values whose level of significance might reach the international level are more likely to satisfy the conditions of authenticity. Only two of these five values are more likely to satisfy the conditions of integrity.

Table 1. The evaluation of the level of significance, authenticity and integrity of the values that New Gourna Village enjoys.

\begin{tabular}{|c|c|c|c|c|}
\hline The heritage values & $\begin{array}{l}\text { The level of } \\
\text { significance }\end{array}$ & Authenticity evaluation & $\begin{array}{l}\text { Integrity evaluation } \\
\text { (the completeness of the attributes) }\end{array}$ & $\begin{array}{l}\text { Integrity evaluation } \\
\text { (the condition of the } \\
\text { attributes) }\end{array}$ \\
\hline Identity value & International & $\begin{array}{l}\text { Does not satisfy the } \\
\text { conditions of authenticity }\end{array}$ & Does not satisfy the conditions of integrity & $\begin{array}{l}\text { Does not satisfy the } \\
\text { conditions of integrity }\end{array}$ \\
\hline Spiritual/religious value & International & $\begin{array}{l}\text { Does not satisfy the } \\
\text { conditions of authenticity }\end{array}$ & Ambivalent result & $\begin{array}{l}\text { Does not satisfy the } \\
\text { conditions of integrity }\end{array}$ \\
\hline $\begin{array}{l}\text { Respect and veneration } \\
\text { values }\end{array}$ & International & $\begin{array}{l}\text { Does not satisfy the } \\
\text { conditions of authenticity }\end{array}$ & Does not satisfy the conditions of integrity & $\begin{array}{l}\text { Does not satisfy the } \\
\text { conditions of integrity }\end{array}$ \\
\hline Historic value & International & $\begin{array}{l}\text { Does not satisfy the } \\
\text { conditions of authenticity }\end{array}$ & Does not satisfy the conditions of integrity & $\begin{array}{l}\text { Does not satisfy the } \\
\text { conditions of integrity }\end{array}$ \\
\hline Age value & National & $\begin{array}{l}\text { Does not satisfy the } \\
\text { conditions of authenticity }\end{array}$ & Does not satisfy the conditions of integrity & $\begin{array}{l}\text { Does not satisfy the } \\
\text { conditions of integrity }\end{array}$ \\
\hline Aesthetic value & International & $\begin{array}{l}\text { Satisfies that conditions of } \\
\text { authenticity }\end{array}$ & Does not satisfy the conditions of integrity & $\begin{array}{l}\text { Satisfies that conditions of } \\
\text { integrity }\end{array}$ \\
\hline Architectural value & International & Ambivalent result & Does not satisfy the conditions of integrity & $\begin{array}{l}\text { Satisfies that conditions of } \\
\text { integrity }\end{array}$ \\
\hline Townscape and urban values & International & $\begin{array}{l}\text { Satisfies that conditions of } \\
\text { authenticity }\end{array}$ & Satisfies that conditions of integrity & $\begin{array}{l}\text { Satisfies that conditions of } \\
\text { integrity }\end{array}$ \\
\hline $\begin{array}{l}\text { Landscape and ecological } \\
\text { values }\end{array}$ & International & $\begin{array}{l}\text { Satisfies that conditions of } \\
\text { authenticity }\end{array}$ & Satisfies that conditions of integrity & $\begin{array}{l}\text { Satisfies that conditions of } \\
\text { integrity }\end{array}$ \\
\hline Scientific value & International & $\begin{array}{l}\text { Does not satisfy the } \\
\text { conditions of authenticity }\end{array}$ & Does not satisfy the conditions of integrity & $\begin{array}{l}\text { Does not satisfy the } \\
\text { conditions of integrity }\end{array}$ \\
\hline Functional value & International & $\begin{array}{l}\text { Satisfies that conditions of } \\
\text { authenticity }\end{array}$ & Satisfies that conditions of integrity & $\begin{array}{l}\text { Does not satisfy the } \\
\text { conditions of integrity }\end{array}$ \\
\hline Economic value & International & $\begin{array}{l}\text { Satisfies that conditions of } \\
\text { authenticity }\end{array}$ & Does not satisfy the conditions of integrity & $\begin{array}{l}\text { Does not satisfy the } \\
\text { conditions of integrity }\end{array}$ \\
\hline Social value & International & Ambivalent result & Ambivalent result & $\begin{array}{l}\text { Satisfies that conditions of } \\
\text { integrity }\end{array}$ \\
\hline Educational value & International & $\begin{array}{l}\text { Does not satisfy the } \\
\text { conditions of authenticity }\end{array}$ & Does not satisfy the conditions of integrity & $\begin{array}{l}\text { Does not satisfy the } \\
\text { conditions of integrity }\end{array}$ \\
\hline Political value & International & $\begin{array}{l}\text { Does not satisfy the } \\
\text { conditions of authenticity }\end{array}$ & Does not satisfy the conditions of integrity & $\begin{array}{l}\text { Does not satisfy the } \\
\text { conditions of integrity }\end{array}$ \\
\hline
\end{tabular}

Source: Data collected and analyzed by the author. 


\subsection{The Justifications of the Heritage Values That New Gourna Village Enjoys}

New Gourna Village was considered to enjoy three emotional values; which are the identity value, the spiritual/religious value and the respect value. The village was considered to enjoy an identity value because of the ability of the property's buildings to stimulate the local community's feelings of their genuine identity. The village was considered to enjoy a religious value, which can be attributed to the contribution of the original buildings, particularly the mosque, towards stimulating the local community's religious feelings. The mosque not only contributes towards stimulating the local community's religious feelings but also plays a key role in its life. The entire local community is closely attached to the mosque. The mosque has also become the major landmark of the village and the surrounding areas. The property was considered to enjoy a respect value because of the ability of its original buildings to stimulate the respect feelings, of the local community and the visitors to the property, towards the designer of the project, who is Hassan Fathy.

The village was considered to enjoy cultural values; which are the historic value, the age value, the aesthetic value, the architectural value, the townscape and urban values, the landscape and ecological values, and the scientific value. The village was considered to enjoy a historic value because of its association with Hassan Fathy, the designer of the village, and because of its association with significant archaeological discoveries in the western bank of the Nile in Luxor. The most relevant and significant discovery of these archaeological discoveries is the discovery of Deir al-Bahari cache of the mummies of 1881 [17]. The village was considered to enjoy an age value although it is an example of recent heritage because of the retention of its original earthen buildings of evidences of weathering and lack of integrity, particularly the wall cracks that can be easily seen everywhere in the village. The fast development of an age value is normal, expected and is a characteristic feature in the case of earthen heritage. The village was considered to enjoy an aesthetic value because of the exceptionally beautiful visual qualities of Hassan Fathy's design of the earthen buildings in the village.

The village was considered to enjoy an architectural value; which can be attributed to the delight, firmness and commodity aspects of Hassan Fathy's design of the earthen buildings, as well as to their sustainability qualities. These sustainability qualities are associated with the passive energy qualities of the traditional architectural paradigms that have been heavily employed in the design of the buildings in the village, such as the internal courtyards and the vaults and domes used as roofing elements. In addition to the previous traditional architectural paradigms, the previous sustainability qualities are attributed to the natural building material used in the construction of the original buildings in the village, which is earth, and its recyclable qualities, and are also attributed to the exceptional passive energy qualities of this traditional building material. Earth has always been considered to enjoy low thermal conductivity characteristics compared with other building materials and a considerable heat lagging characteristics [22]. Consequently, earthen buildings can provide a cool internal environment during day-time in hot arid regions, such as the southern parts of Egypt and particularly Luxor, thus limiting the need for artificial air-conditioning systems. The village was considered to enjoy a townscape value; which is attributed to many aspects including the outward views into the Colossi of Memnon, Old Gourna Village, and the green fields to the north of the village. Finally, the village was considered to enjoy a scientific value, which is attributed to its ability to provide answers to scientific problems largely associated with the techniques used in the construction of adobe houses.

The village was considered to enjoy five use values; which are the functional value, the economic value, the social value, the educational value, and the political value. New Gourna Village was considered to enjoy a functional value because many of the buildings designed by Hassan Fathy are still in use. The economic value of the village is attributed to its ability to encourage tourism because of its location close to the major tourism attractions in Luxor. The village was considered to enjoy a social value, which is attributed to the ability of its squares to facilitate the local community's social connections. What emphasizes the social value of the village is that some of the semiprivate squares inside the village (Figure 4) are used for social events, such as wedding celebrations. The village was considered to enjoy an educational value because of its ability to provide the new generation with some knowledge about their history mainly because of the village's proximity to the nearby ancient Egyptian archaeological sites, and its historic association with them. Finally, New Gourna Village was considered to enjoy a political value, which is attributed to its association with Hassan Fathy's political principles that focused on the role of architecture in re-establishing the nation's genuine identity as a reaction against colonialism. Steele [14] has addressed the political dimension in Hassan Fathy's works and his architectural ideas.

\subsection{Evaluating the Level of Significance of the Historic Value of New Gourna Village}

New Gourna Village was considered to enjoy a historic value because it satisfied four indicators of the historic value, which are the property's age, the property's historic association with people or events in the past, the technological qualities of the property, and its ability to provide knowledge about the past. The historic value of the village, as indicated by its age, was considered to be experienced on the national level. The reason why the significance of the historic value was evaluated to reach the national level, as indicated by the time when the property was built, is that, this time represents the late royal family era and the time to which modern Egypt's early intellectuals belong. The resurrection of modern Egypt is largely attributed to the contributions and efforts of that generation of intellectuals; to which Abbas Mahmud al-Aqqad (18891964) [23], Taha Hussein (1889-1973) [24], Hassan Fathy (1900-1989) [14, 16], and others belong. 


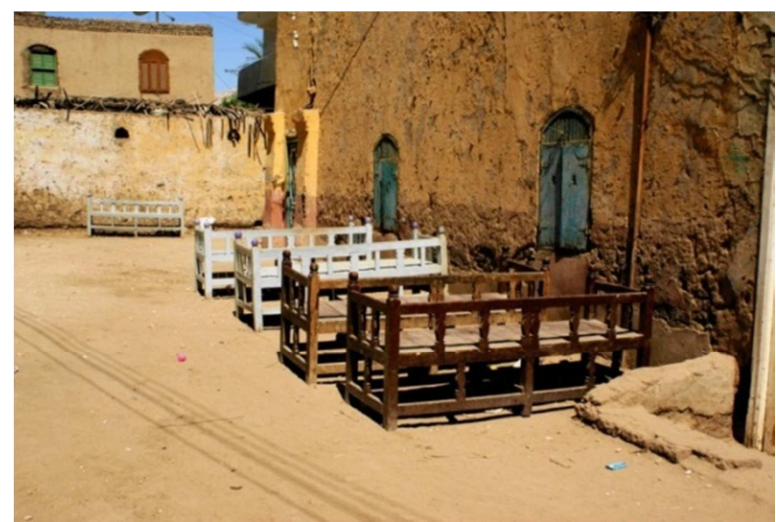

Source: Photograph by the author, September 2011.

Figure 4. A photograph of one of the semiprivate squares that are used for social and familial events, such as wedding celebrations, in New Gourna.

The historic value of the village, as indicated by its historic associations, was considered as a true representation of the genuine Egyptian culture. The property is historically associated with Hassan Fathy, whose architectural vocabularies truly represent the genuine Egyptian culture and identity. The historic value of the village, as indicated by its historic associations, was considered to be experienced and appreciated on the international level. The works of Hassan Fathy, particularly New Gourna Village, have been appreciated on the international level. The Aga Khan Award awarded to Hassan Fathy in 1980, as well as the UIA Gold Medal awarded to him in 1984 [25], emphasizes this international appreciation.

The historic value of the village, as indicated by its technological qualities, was considered to have been experienced and appreciated on the international level. The technological qualities of the property are represented by its building material, which is earth. Using earth as a building material has been appreciated worldwide because of its sustainability and passive energy qualities. The sustainability qualities of New Gourna Village that are mainly associated with its building material, which is earth, have also been appreciated on the international level [15]. The technological qualities of the village have been interchanged within a geographical region that extends beyond the national borders, and over a span of time that extends from the ancient Egyptian time till present time. Simone Swan's initiative in Texas, which has been influenced by the works of Hassan Fathy and by the Nubian vaulting system that he used [18], emphasizes the interchange of New Gourna's technological qualities and historic value [26]. The historic value of the village, as indicated by its ability to provide knowledge about the past, was considered to be appreciated on the international level. This internationally appreciated knowledge is associated with the ancient Egyptian civilization and the major archaeological finds that took place in the surroundings of the village.

Based on the previous analysis, the overall level of significance of the historic value was considered to reach the international level (Table 2). Subsequently, the contributing elements of the historic value were identified. These elements involve the various buildings in the village designed by Hassan Fathy, the association of the buildings in the property with Hassan Fathy and his architectural principles, and the near-by archaeological sites. Consequently, the attributes that are relevant to each element were identified. The attributes that were considered relevant to the buildings designed by Hassan Fathy are form and design, materials and substance; traditions, techniques and management system; and location and setting. The attributes that were considered relevant to the association of the village with Hassan Fathy involve form and design, materials and substance, use and function; traditions, techniques and management systems; location and setting, and spirit and feeling. Finally, the attributes that were considered relevant to the near-by archaeological sites involve materials and substance, use and function, and location and setting.

Table 2. The evaluation of the level of significance of the historic value of New Gourna Village.

\begin{tabular}{|c|c|c|c|}
\hline Indicators of the historic value & Criteria justifying the level of significance & $\begin{array}{l}\text { Maximum potential } \\
\text { level of significance }\end{array}$ & $\begin{array}{l}\text { Overall level of } \\
\text { significance }\end{array}$ \\
\hline $\begin{array}{l}\text { The property's age indicates its historic } \\
\text { value. }\end{array}$ & The level at which the value is appreciated is the national level. & National significance & \multirow{4}{*}{$\begin{array}{l}\text { International } \\
\text { significance }\end{array}$} \\
\hline $\begin{array}{l}\text { The property is associated with events, } \\
\text { or people, in the past, or it is the work } \\
\text { of an outstanding designer or architect. }\end{array}$ & $\begin{array}{l}\text { The value is a true representation of the Egyptian culture. } \\
\text { The level at which the value is appreciated is the international level. }\end{array}$ & $\begin{array}{l}\text { International } \\
\text { significance }\end{array}$ & \\
\hline $\begin{array}{l}\text { The technological qualities of the } \\
\text { property indicate its historic value. }\end{array}$ & $\begin{array}{l}\text { The value is a true representation of the Egyptian culture. } \\
\text { The level at which the value is appreciated is the international level. } \\
\text { The value is interchanged within a geographical region and over a } \\
\text { span of time. }\end{array}$ & $\begin{array}{l}\text { International } \\
\text { significance }\end{array}$ & \\
\hline $\begin{array}{l}\text { The property can provide knowledge } \\
\text { about the past. }\end{array}$ & $\begin{array}{l}\text { The value is a true representation of the Egyptian culture. } \\
\text { The level at which the value is appreciated is the international level. } \\
\text { The value is interchanged over a span of time. }\end{array}$ & $\begin{array}{l}\text { International } \\
\text { significance }\end{array}$ & \\
\hline
\end{tabular}

Source: Data collected and analyzed by the author.

\subsection{Evaluating the Authenticity and Integrity of the Historic Value of New Gourna Village}

To evaluate the authenticity of the historic value (Table 3 ), the extent of truthfulness, genuineness and credibility at which the relevant attributes, of each relevant contributing element, express the historic value was evaluated. The design, and the location and setting of the buildings designed by Hassan Fathy were considered slightly genuine. The many internal and external alterations carried out to these buildings 
(Figure 5), as well as the many unsympathetic modern developments that overwhelmed the setting of the village (Figure 6), are the reasons why the authenticity of these attributes was considered to have declined substantially. On the other hand, the materials and the construction techniques of the same contributing element were considered fairly genuine. The design, setting, and spirit and feeling that emphasize the historic association of the village with Hassan Fathy were considered slightly genuine; while the materials, use, and construction techniques associated with the previous contributing element were considered fairly genuine. Finally, the materials of the near-by archaeological sites were considered very genuine, while their function and location were considered totally genuine. The very few alterations carried out to these archaeological sites are the reason why their materials and substances were considered very genuine instead of totally genuine. Most of these minor alterations are associated with the management and interpretation of these archaeological sites (Figure 7). The overall evaluation of the authenticity of the historic value was ambivalent because five attributes were considered slightly genuine while five other attributes were considered fairly genuine. Therefore, the overall evaluation of the authenticity of the historic value indicates that the historic value can be considered either slightly genuine or fairly genuine, which are both less genuine than the very genuine and totally genuine thresholds. The previous finding emphasizes the considerable decline of the authenticity of the historic value.

The evaluation of the integrity of the historic value (Table 3 ) focused on two aspects which are the completeness and the condition of the attributes associated with every contributing element of the historic value. The findings indicated that few materials and few elements; which express and represent the form, the traditional construction techniques, and the setting of the buildings designed by Hassan Fathy; survived. The materials and the elements that express Hassan Fathy's original design and construction techniques of the buildings he designed in New Gourna were considered in a poor condition. Finally, the setting of the buildings designed by Hassan Fathy was considered in a good condition. Hassan Fathy's house is one of the most significant buildings in the village that represent the dramatic decline of the integrity of the materials of the buildings he designed in the village. The walls of the house suffer from the spread of deep cracks while small sections of the walls have already begun to crumble, such as the buttress in the side elevation (Figure 8). At the back of the house, a small section of the claustra has collapsed while the rest of the claustra is in a very bad condition (Figure 9).

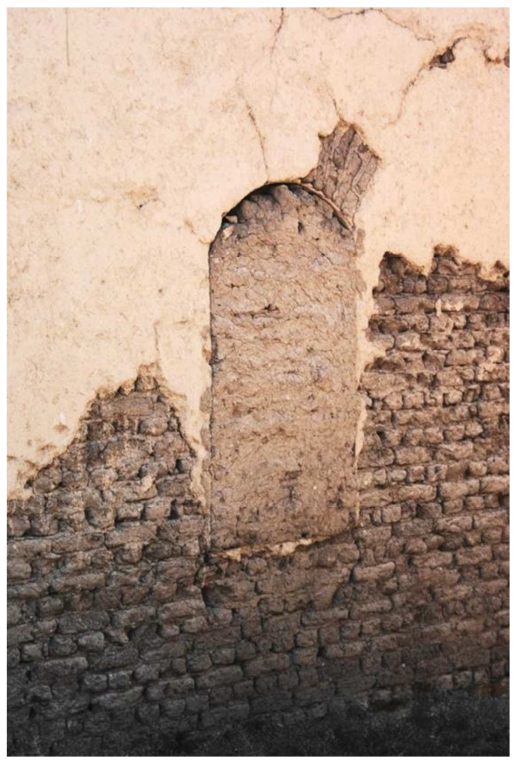

Source: Photograph by the author, September 2011.

Figure 5. An example of the many alterations from which most of the buildings designed by Hassan Fathy in New Gourna Village suffer. Alterations to windows, such as this example, are some examples of a large list of unsympathetic alterations carried out to doors, facades, internal elements, and internal subdivisions of the houses in the village.

Table 3. The evaluation of the authenticity and integrity of the historic value of New Gourna Village.

\begin{tabular}{|c|c|c|c|c|}
\hline $\begin{array}{l}\text { The contributing } \\
\text { elements }\end{array}$ & The relevant attributes & $\begin{array}{l}\text { The evaluation of } \\
\text { authenticity }\end{array}$ & $\begin{array}{l}\text { The evaluation of integrity (the } \\
\text { completeness of the attributes) }\end{array}$ & $\begin{array}{l}\text { The evaluation of integrity (the } \\
\text { condition of the attributes) }\end{array}$ \\
\hline \multirow{4}{*}{$\begin{array}{l}\text { The various buildings in } \\
\text { the property designed } \\
\text { by Hassan Fathy }\end{array}$} & Form and design & Slightly genuine & Few relevant elements are existent & Poor condition \\
\hline & Materials and substance & Fairly genuine & Few relevant elements are existent & Poor condition \\
\hline & $\begin{array}{l}\text { Traditions, techniques and } \\
\text { management systems }\end{array}$ & Fairly genuine & Few relevant elements are existent & Poor condition \\
\hline & Location and setting & Slightly genuine & Few relevant elements are existent & Moderate condition \\
\hline \multirow{5}{*}{$\begin{array}{l}\text { The association of the } \\
\text { property with Hassan } \\
\text { Fathy and his } \\
\text { architectural principles }\end{array}$} & Form and design & Slightly genuine & Many relevant elements are existent & Good condition \\
\hline & Use and function & Fairly genuine & Few relevant elements are existent & Poor condition \\
\hline & $\begin{array}{l}\text { Traditions, techniques and } \\
\text { management systems }\end{array}$ & Fairly genuine & Many relevant elements are existent & Moderate condition \\
\hline & Location and setting & Slightly genuine & Few relevant elements are existent & Moderate condition \\
\hline & Spirit and feeling & Slightly genuine & Hardly any relevant elements are existent & Dilapidated elements \\
\hline The near-by & Materials and substance & Very genuine & All the relevant elements are existent & Excellent condition \\
\hline $\begin{array}{l}\text { archaeological sites that } \\
\text { are historically }\end{array}$ & Use and function & Totally genuine & All the relevant elements are existent & Excellent condition \\
\hline $\begin{array}{l}\text { associated with the } \\
\text { property }\end{array}$ & Location and setting & Totally genuine & All the relevant elements are existent & Excellent condition \\
\hline $\begin{array}{l}\text { The overall evaluation } \\
\text { of the historic value }\end{array}$ & & Ambivalent result & Few relevant elements are existent & Poor condition \\
\hline
\end{tabular}

Source: Data collected and analyzed by the author. 
In relation to the historic association with Hassan Fathy, many elements expressing his architectural ideas; in terms of the buildings' design, materials and construction techniques; were considered to have survived. The previous evaluation focused mainly on the original design of the diverse architectural elements that reflect Hassan Fathy's ideas rather than the physical condition of the materials that represent this design. Few elements reflecting the functions and the setting of the buildings in the village, which agree with the architect's ideas, were considered to have survived. The many alterations carried out to the setting of the original buildings that reflect Hassan Fathy's ideas and to the setting of the village as a whole represent the reason of the previous evaluation. Finally, hardly any of the elements that reflect the genuine spirit and feeling of the village, which agree with Hassan Fathy's ideas, were considered to have survived. The prevalence of modern unsympathetic new developments that detract from the genuine spirit and feeling of the village, the dramatic decline of the number of the buildings designed by Hassan Fathy, and the many alterations carried out to the village as a whole are the main reasons why the completeness of the spirit and feeling attribute was evaluated as hardly any elements survived. The previous alterations not only involve those carried out to the few remaining buildings designed by Hassan Fathy but also involve the alterations carried out to street surface materials and landscape elements, particularly the introduction of tarmac streets in the village. The architectural elements, whose design emphasizes the historic association with Hassan Fathy, were considered in a good condition. The materials and the function of these elements were considered in a poor condition. Finally, the present-day overall spirit and feeling of the village was considered incapable of reflecting Hassan Fathy's original intentions.

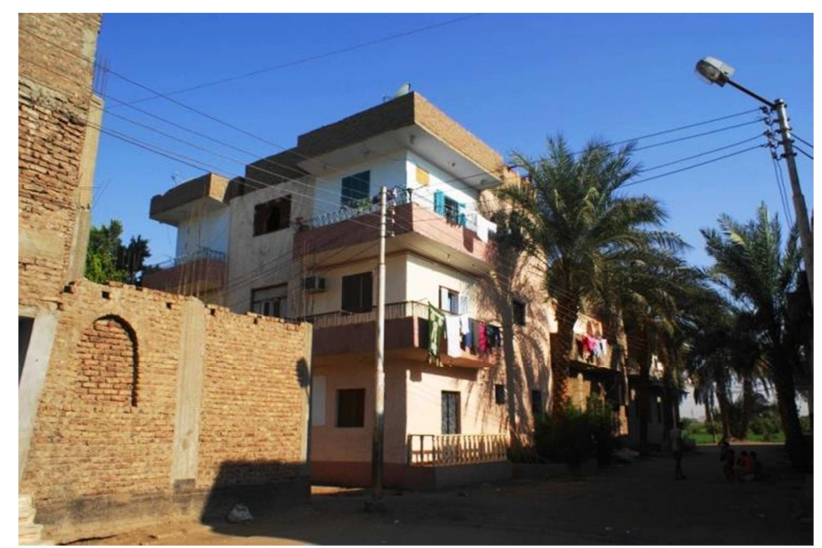

Source: Photograph by the author, September 2011.

Figure 6. An example of the unsympathetic modern developments that enjoy a very poor architectural quality, which overwhelmed New Gourna Village and replaced many of the houses designed by Hassan Fathy.

In relation to the near-by archaeological sites, the integrity of all the relevant attributes was considered impeccable. The overall evaluation of the integrity of the historic value, in relation to the completeness of the relevant attributes, revealed the survival of few architectural elements that express the historic value. On the other hand, the evaluation of the integrity of the historic value, in relation to the condition of the relevant attributes, revealed the poor condition of these elements. The level of significance of the other heritage values that New Gourna enjoys and their authenticity and integrity were evaluated according to the same method applied in the case of the historic value.

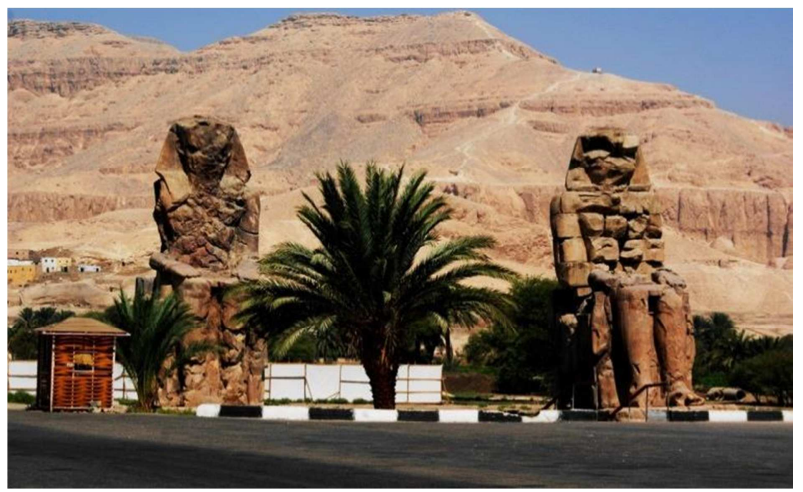

Source: Photograph by the author, September 2011.

Figure 7. The Colossi of Memnon represent one of the key archaeological sited located very close to New Gourna Village. The setting of the archaeological site has undergone few alterations that are meant to enhance the management and interpretation of the site.

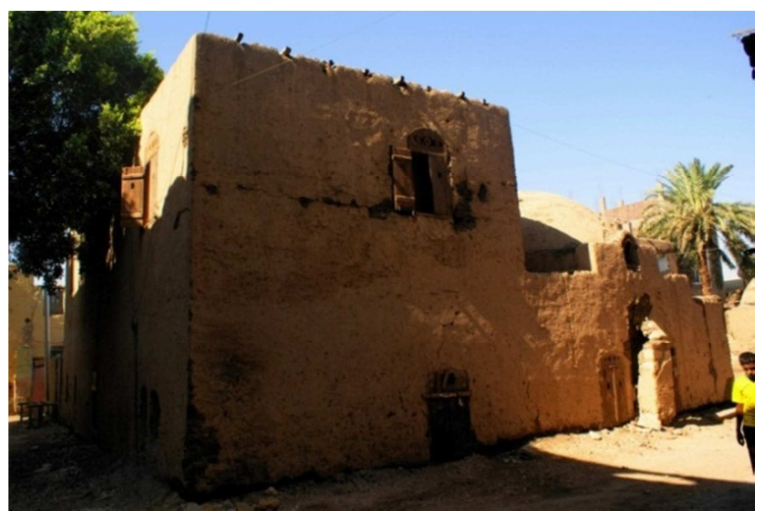

Source: Photograph by the author, September 2011.

Figure 8. Hassan Fathy's house in New Gourna. The walls of the house suffer from the spread of deep cracks that resulted in the partial collapse of the buttress in the house's side façade.

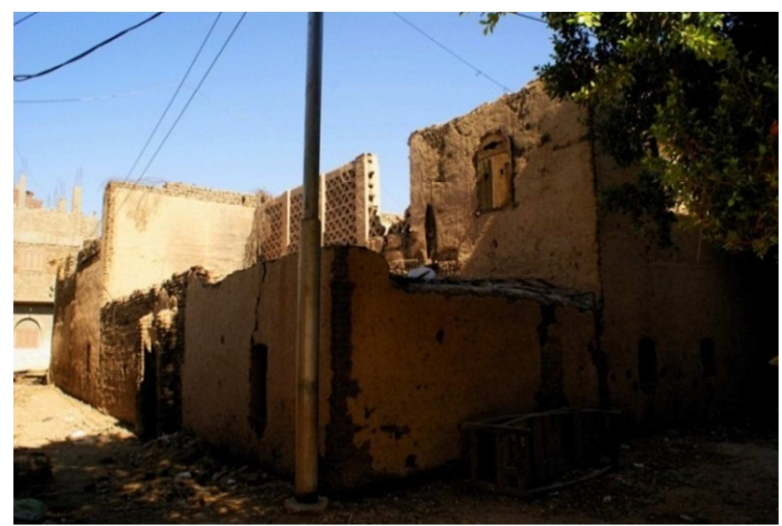

Source: Photograph by the author, September 2011.

Figure 9. The claustra at the rear façade of Hassan Fathy's house. 


\section{Conclusions}

The previous analysis indicates that New Gourna Village enjoys a large number of heritage values whose level of significance is expected to reach the international level. These heritage values, which amount to 15 values, involve values such as the spiritual/religious value, the historic value, the architectural value, the townscape and urban values, and the functional value. Except for the age value, the level of significance of the other 14 values is expected to reach the international level. The international level of significance of these heritage values, and the village as a whole, is expected to allow New Gourna Village the chance to qualify for the Outstanding Universal Value status. However, the findings revealed that most of the heritage values that New Gourna Village enjoys are not expected to satisfy the conditions of authenticity and integrity. The findings revealed that out of the 14 heritage values whose level of significance was considered to reach the international level of significance only five values are expected to satisfy the conditions of authenticity. The findings also revealed that only two of these five heritage values are expected to satisfy the conditions of integrity.

The findings indicated that New Gourna Village suffers from a dramatic decline of its authenticity and integrity. The major aspects that emphasize the decline of the authenticity of the village involve the many internal and external alterations carried out to the buildings designed by Hassan Fathy in the village. The overwhelming spread of poor and unsympathetic examples of new developments throughout the village and around it is another significant aspect of the decline of the village's authenticity. These aspects also involve the continuous demolition of the buildings designed by Hassan Fathy in the village and the replacement of these buildings by modern concrete buildings that enjoy very limited architectural qualities. On the other hand, the major aspects that emphasize the decline of the integrity of the village involve the decline of the physical condition of the few remaining houses designed by Hassan Fathy in the village and the spread of seriously threatening deep cracks throughout their earthen walls. The collapse of many of the earthen buildings designed by Hassan Fathy and their architectural elements is another aspect. Finally, the considerable decline of the number of the earthen buildings designed by Hassan Fathy in the village should be considered a serious threat and a serious aspect of the decline of the village's integrity. The local government's limited control over the quality of the new developments introduced inside and around the village should be considered among the key factors that led to the decline of the village's authenticity and integrity.

The previous findings suggest that serious conservation measures should be carried out to New Gourna Village so that the village successfully satisfies the conditions of authenticity and integrity. Furthermore, these conservation measures should involve adopting all the available statutory tools that allow the government the right to closely control the quality of the new developments introduced inside the village. These statutory tools might involve the designation of the entire village as an Area Enjoying a Distinctive Value [27], and the listing of the buildings designed by Hassan Fathy in the village under the Act no. 144 as Buildings and Structures Enjoying a Distinctive Architectural Style [13]. The study supports all the efforts undertaken by the World Heritage Centre to preserve New Gourna Village and recommends the continuation of these efforts. The study also recommends that the statement of Outstanding Universal Value of the World Heritage Site in Luxor should be revised so as to acknowledge the contribution of New Gourna Village towards the Outstanding Universal Value of the World Heritage Site.

\section{References}

[1] UNESCO, Expert Meeting on the "Global Strategy" and thematic studies for a representative World Heritage List. Paris: United Nations Educational, Scientific and Cultural Organisation, 1994.

[2] van Oers, R. and Haraguchi, S., World Heritage papers 5, Identification and Documentation of Modern Heritage. Paris: UNESCO World Heritage Centre, 2003.

[3] Cantacuzino, Sherban, ARCHITECTURE IN CONTINUITY, BUILDING IN THE ISLAMIC WORLD TODAY. New York: Aperture, 1985.

[4] Abdel Tawab, A. G., "Hassan Fathy's humane considerations in design and the significance of New Gourna," in Mileto, C., Vegas López-Manzanares, F., García-Soriano, L., and Cristini, V. (eds.), Vernacular and Earthen Architecture, Conservation and Sustainability, SOStierra 2017 International Conference on Vernacular Earthen Architecture, Conservation and Sustainability; Proc., Intern. Conf., Valencia, 14-16 September 2017. London: CRC Press, Taylor \& Francis Group.

[5] UNESCO World Heritage Centre, Egypt - UNESCO World Heritage Centre [Online]. Paris: UNESCO World Heritage Centre, n.d. Available from:

http://whc.unesco.org/en/statesparties/eg [Accessed 28 July 2018].

[6] UNESCO, Safeguarding project of Hassan Fathy's New Gourna Village, A UNESCO Initiative. Paris: United Nations Educational, Scientific and Cultural Organisation, 2011.

[7] UNESCO, Operational Guidelines for the Implementation of the World Heritage Convention. Paris: United Nations Educational, Scientific and Cultural Organisation, 2017.

[8] Supreme Council of Antiquities, "Ancient Thebes with its Necropolis" Overlayed on ESA 1:2500 Cadastral Maps. Cairo: Supreme Council of Antiquities, 2006.

[9] Feilden, Bernard M., Conservation of Historic Buildings. Oxford: Architectural Press, 2003.

[10] Mason, Randall, Assessing Values in Conservation Planning: Methodological Issues and Choices, in Marta de la Torre (ed.) Assessing the Values of Cultural Heritage. Los Angeles: The Getty Conservation Institute, 2002.

[11] English Heritage, Sustaining the historic environment: new perspective on the future. London: English Heritage, 1997. 
[12] Jokilehto, J. (2006). WORLD HERITAGE: DEFINING THE OUTSTANDING UNIVERSAL VALUE. City \& Time 2 (2), $1-10$.

[13] Abdel Tawab, Ayman G., Introduction to Urban Conservation. Saarbrücken: LAP LAMBERT Academic Publishing, 2013.

[14] Steele, James, AN ARCHITECTURE FOR PEOPLE, THE COMPLETE WORKS OF HASSAN FATHY. London: Thames and Hudson, 1997.

[15] Pyla, Panayiota I. (2007). Hassan Fathy Revisited, Postwar Discourses on Science, Development, and Vernacular Architecture. Journal of Architectural Education 60 (3), 28-39.

[16] Serageldin, Ismail, Hassan Fathy. Alexandria: the Bibliotheca Alexandria, 2007.

[17] Abdel Tawab, Ayman G. (2014). The World Heritage Centre's approaches to the conservation of New Gourna Village, and the assessment of its authenticity and integrity, Alexandria Engineering Journal. Alexandria Engineering Journal 53 (3), 691-704.

[18] Fathy, Hassan, Architecture for the Poor. Cairo: the American University in Cairo Press, 2000.

[19] Save the Heritage of Hassan Fathy, Save the Heritage of Hassan Fathy [Online]. Geneva: Save the Heritage of Hassan Fathy, n.d. Available from: http://fathyheritage.over-blog.com/ [Accessed 24 March 2018].
[20] World Monuments Fund, New Gourna Village: Conservation and Community. New York: World Monuments Fund, 2011.

[21] World Monuments Fund, New Gourna Village | World Monuments Fund [Online]. New York: World Monuments Fund, 2017. Available from: http://www.wmf.org/project/newgourna-village\# [Accessed 25 March 2018].

[22] Minke, Gernot, BUILDING WITH EARTH, Design and Technology of a Sustainable Architecture. Berlin: Birkhaüser - Publishers for Architecture, 2013.

[23] Farag, al-Said Ahmed, Abbas Mahmud al-Aqqad and the Journeys of the North and South. Al-Mansura: Dar al-Asdiqaa for Publishing, 2010. (in Arabic).

[24] Attia, Salah, In Memory of the Dean of the Arab Literature, Literature Ordeal of his Readers. Dar al-Gomhuria for Publishing, 2010. (in Arabic).

[25] Abdel Tawab, Ayman G. (2018). The Conservation of New Gourna Village According to Hassan Fathy's Philosophy and Ideas. Journal of Architecture and Planning 30 (1), 145-164.

[26] Doughty, Dick (1999). From the Nile to the Rio Grande. SAUDI ARAMCO World 50 (4), 47-52.

[27] Abdel Tawab, Ayman G. (2012). Area-based conservation: The strengths and weaknesses of the Egyptian emerging experience in area-based conservation. Alexandria Engineering Journal 51 (2), 137-152. 